\title{
Exploration of Accounting Talent Training Mode in Higher Vocational Colleges
}

\author{
Qinyu Zhang \\ Chaoshan Vocational and Technical College, Jieyang, 515343, China
}

Key words: higher vocational, accounting major, talent training mode

\begin{abstract}
Accounting major is strongly practical and technical, and its talent training mode refers to a system and framework of training skilled accounting talents. Traditional Chinese accounting talent training mode in higher vocational colleges is not very ideal, as it attaches too much importance to teaching students theoretical knowledge while seriously ignoring training and improvement of students' practical ability. Thus, to solve problems in this talent training mode, this paper puts forward a new talent training mode for higher vocational accounting majors, and rebuilds higher vocational accounting talent training mode, in order to make students better adapt to development requirements of economic society.
\end{abstract}

\section{Introduction}

Accounting talent training mode refers to an operating mechanism that trains talents with certain accounting skills through educational concepts or thoughts. This mechanism has a quite stable structural state, and combines various factors organically based on certain talent training goals, and thus carries out accounting talent training activities continuously. It should be said that for higher vocational colleges as main places for training senior skilled talents, the accounting talent training mode is directly related to the quality and level of accounting talent training. Higher vocational colleges shall change traditional accounting talent training mode as soon as possible, be truly led by market demand, and train accounting talents that meet requirements of economic and social development by combining learning with working, to truly make higher vocational accounting talent training mode practical, open and vocational.

\section{Current situation and problems of Chinese higher vocational accounting talent training mode}

Higher vocational accounting talent training mode in current China does not highlight its vocational feature, refers to and imitates accounting talent training mode of undergraduate colleges to a great extent, so that accounting talents of higher vocational colleges cannot adapt to talent demand of current employment market well, which not only wastes seriously higher vocational teaching resources, but also causes employment barriers of higher vocational graduates to a certain extent. Thus, current problems of higher vocational accounting talent training mode include:

(1) Talent training goal cannot adapt to accounting talent demand of the society. The positioning of higher vocational accounting talent training goal is based on neither actual conditions nor actual market demand, but imitates and refers to accounting talent training mode of undergraduate colleges blindly, and the mere difference is that talent training goal of undergraduate colleges is specialized accounting talents while that of higher vocational colleges is applied accounting talents. Essentially, there is not a big difference between both training goals. Therefore, it is believed that higher vocational accounting talent training goal is not accurate or clear enough, so that higher vocational teachers would often teach content that does not comply with students' actual conditions. As a result, teachers feel more difficult in giving classes, resulting in low teaching efficiency and poor teaching effects, while students have not accurate learning positioning because of inaccurate positioning of higher vocational accounting talent training goal, and thus lead to blindness and low efficiency etc during learning.

(2) Lack of a featured course system leads to students' low practical ability. Course teaching system in higher vocational accounting talent training mode has similar defects with talent training 
goal, i.e. mainly imitates and refers to course system in accounting talent training mode of undergraduate colleges. Thus, in higher vocational accounting talent training mode, course system setting of accounting major basically takes discipline as the center and key of teaching, and generally includes basic courses, professional basic courses, specialized courses and practice etc. Among these courses, theoretical accounting courses occupy too much time, while accounting practice has less opportunity and time. Although some of current higher vocational colleges begin to realize the practical and skill features of accounting major and add some practical courses and teaching links appropriately, such practical courses just stay in form and have not provided students with a complete simulated accounting operating environment, and thus could not truly train accounting talents that could adapt quickly to specific work requirements in future posts.

(3) Backward teaching methods result in students' low accounting quality. Higher vocational accounting teaching methods are still traditional ones to a great degree and focus teaching center on classroom teaching, and accounting teachers fail to grasp difficulty degree of teaching content rationally during teaching. As a result, the entire teaching content tends to be difficult and thus wastes lots of teaching time and resources, resulting in greatly reduced practical links during higher vocational accounting teaching and insufficient time for practical teaching for students. Besides, many higher vocational teachers have only quite adequate theoretical accounting knowledge, but have not very sufficient practical accounting experience or carry out in-depth survey and research in frontline of accounting posts, and couldn't simulate accurate accounting working environment for students' accounting practice, and thus lead to lack of effectiveness and pertinence of the entire accounting teaching and students’ low comprehensive accounting quality.

\section{Repositioning of accounting talent training goal in higher vocational colleges}

The so-called talent training goal is to reach certain talent standards and requirements after a certain time of education and training activities. So, for higher vocational accounting major, the talent training goal shall start from higher vocational education features, cultivate and improve their accounting application ability from the perspective of training students' basic theoretical knowledge and qualities, so that they could truly become practical accounting talents that enterprises and local regions need in future accounting posts. It should be said that accounting talents would be engaged in frontline of finance and accounting in the future, and the basic job requirement is to provide true, reliable and complete accounting and supervision of enterprises' economic business and complete the entire accounting cycle work according to manual processes and computer requirements. Thus, the goal of higher vocational accounting talent training should be training senior skilled and applied accounting talents with theoretical accounting foundation and certain practical accounting operating ability for the frontline of modern enterprise production, management and services, in order to meet development requirements of socialist market economy system. This requires higher vocational colleges to do well in the following aspects of work to achieve repositioning of accounting talent training goal:

(1) Do well in professional survey on accounting. Scientific positioning of higher vocational accounting talent training goal cannot be separated from scientific and rational survey. This requires higher vocational colleges to provide some time and manpower to carry out multi-channel and multi-form professional survey. For instance, higher vocational colleges could survey accountants and intermediaries by interviews and letters of survey etc, and investigate students majoring in accounting through telephone interviews etc. Such survey would provide more accurate first-hand talent demand information for accurate positioning of higher vocational accounting talent training mode, and thus point out training direction and tasks for higher vocational accounting talent training, and enable these colleges to modify and complete talent training programs according to information of this survey.

(2) Strengthen communication and exchanges with frontline experts. Repositioning of higher vocational accounting talent training mode shall further start from frontline experts, and strengthen exchanges and communication with these accounting talents, as they are active senior talents on frontline accounting posts, have rich work experience and advanced accounting concepts, and have 
more appropriate positioning of accounting talents required in actual work. Therefore, during accounting talent training, higher vocational colleges shall accept suggestions and guidance of these experts and scholars carefully and modestly in terms of accounting major setting, talent standards and construction of course system etc, and could also hire them to give lessons in colleges directly, so as to make more appropriate and feasible accounting talent training programs and receive supervision and guidance of experts during implementation of talent training programs.

(3) Give play to teachers' active role through teaching reform. Repositioning of accounting talent training mode of higher vocational colleges shall also start from frontline teachers, and lead them to carry out accounting teaching reform proactively and actively, so as to provide accurate and operable possibility and opportunity for accounting talent training programs. For example, higher vocational accounting teachers could recombine teaching courses, carry out innovative teaching methods etc, and try to promote continuous perfection and improvement of higher vocational accounting teaching course system. Besides, higher vocational colleges shall also fully motivate many aspects of power and ability of the society, professional guiding committee, graduates and students in school etc to reposition accounting teaching methods, promote further advance of teaching reform, determine appropriate talent training goals with the guidance of professional teachers, and thus truly give play to the subjective role of professional teachers.

\section{Innovation and rebuilding of higher vocational accounting talent training mode}

Based on the above problems in training mode and repositioning of training goals, higher vocational colleges shall try to carry out innovation and rebuilding of accounting talent training mode, in order to truly cultivate high-quality and applied accounting talents that meet requirements for the society. Specifically, innovation and rebuilding of higher vocational accounting talent training mode can be carried out in the following ways:

(1) Do well in job location of accounting graduates. In today's society, accounting work requires high-quality professional talents, as modern economy is a highly complex and professional system and requires a large cooperation team consisting of more professionals to conduct accounting work. Then, higher vocational colleges shall adjust the current situation that their graduates have grandiose aims but puny abilities in the employment market, and lead them to establish correct employment attitude, calm down and do good work in the most grass-roots accounting posts, be slightly inferior to accountants graduated from undergraduate colleges, and gradually find their accounting work positioning in the society, such as serving as cashiers or accountants etc in enterprises and public institutions or audit assistants etc in accounting intermediaries.

(2) Establish a talent training mode of combining learning with working. Higher vocational colleges are education places that mainly train students' vocational ability. Therefore, accounting teaching of higher vocational colleges shall fully realize this feature, take employment as teaching orientation, take training and improving students' vocational ability as the main objective, and try to guide students to combine organically knowledge learned in classes with extracurricular practical activities, so that students could get rich social practical experience in colleges, reduce pre-job training time in enterprises and public institutions, reduce labor costs of enterprises and public institutions substantially, and improve their adaptability. In fact, lots of international higher vocational talent training modes use the mode of “combining learning with working”, which is very consistent with characteristics and requirements of higher vocational education. So, higher vocational colleges shall strengthen practical teaching of students, and build practice and training bases and a group of full-time and part-time double-quality teachers. However, lots of current higher vocational colleges lack double-quality teachers the most, and thus are required to attach importance to practice of accounting teachers and cultivation of development ability, encourage them to actively participate in various training or further education activities, hire some experts and professors to guide teaching etc, or cooperate with accounting firms etc, so as to improve these teachers' comprehensive ability and their teaching ability effectively.

(3) Carry out a teaching method integrated with theories and practice. Teaching method 
integrated with theoretical knowledge teaching and practical skill training shall be carried out during higher vocational accounting teaching. This requires higher vocational colleges to start from students' professional skill level, organize and carry out practical teaching by project-oriented and task-driven teaching method. Of course, this does not mean to abandon teaching of theoretical knowledge, but to promote interaction and integration of theoretical teaching with practical teaching in accounting major in accordance with the basic principle of studying in order to apply based on theoretical teaching, and make students acquire more accounting knowledge and skills within the required time. Thus, accounting teachers shall adopt a variety of teaching methods, such as situational, experiential, interesting and simulated etc, to arouse students' interest in learning accounting, and fully mobilize students' imaginary thinking ability, and combine theoretical courses with practical courses organically in terms of teaching arrangement, so that students could learn while practicing and practice while learning. In addition, higher vocational colleges should also build a three-dimensional teaching system, so that students could integrate deeply "teaching, learning, practicing and working” in practical training and thus achieve zero training in future work through training of practical posts. Of course, during such practice, higher vocational colleges shall also carry out appropriate reform of teaching content and course system, implement talent training mode that combines professional certificate examination with course examination, and thus enhance students' employment competitiveness in the market.

\section{Conclusions}

In short, during building of accounting talent training mode, higher vocational colleges shall conduct scientific and rational positioning of talent training goal, and then reform specialized accounting course teaching system, build on-campus accounting training centers with "real enterprise situation" for students, establish a group of double-quality teachers with appropriate full-time and part-time proportions etc, design a good higher vocational accounting talent training mode, provide feasible conditions for reform and innovation of accounting talent training mode, and rebuild a flexible quality evaluation system while expanding talent training ways constantly, in order to truly train high-quality accounting talents.

\section{References}

[1] He Jie. On Building Accounting Talent Training in Higher Vocational Colleges under the New Situation [J]. Management and Fortune, 2010 (3)

[2] Lan Zizhen, Xu Wenjie. Building and Implementation of Employment-oriented Higher Vocational Accounting Practical Course System [J]. Chinese Vocational and Technical Education, 2008 (4)

[3] Liu Mingfei. Study and Practice of " $2+1$ " Talent Training Mode for Higher Vocational Accounting Major [J]. Science \& Technology Economy Market, 2007 (8)

[4] Wang Qingchun. Thinking on Reform of Accounting Information Talent Training in Higher Vocational Education [J]. China Economist, 2008 (1) 